\title{
Biodiversity and food security: from trade-offs to synergies
}

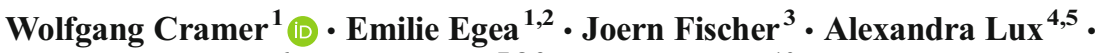 \\ Jean-Michel Salles $^{6}$ - Josef Settele ${ }^{7,8,9} \cdot$ Muriel Tichit $^{10}$
}

Received: 19 March 2017 / Accepted: 24 March 2017 /Published online: 18 April 2017

(C) Springer-Verlag Berlin Heidelberg 2017

Biodiversity and food security are connected in many ways. Across scales from genes to species, landscapes, and biomes, biodiversity is an important resource for humanity. It is the key for a broad range of services provided by ecosystems. Biodiversity helps regulate the nutrient cycle and water (e.g., floods) and mitigates impacts of climate change. Biodiversity is also of direct importance for human well-being and for cultural and other values including recreation. The provisioning of clean water and diverse food supply makes it vital for all people. Biodiversity at all levels, including the diversity of genes, species, and ecosystems, is lost at alarming rates. Critical factors for these trends are habitat destruction, global warming, and the uncontrolled spread of alien species. Pollution, nitrogen deposition, and shifts in precipitation further affect biodiversity.

Food security faces significant challenges due to population growth, poverty, globalization, climate change, and other factors. Supplying healthy food to all citizens is crucial for global development - to reach it, not only food production but also equitable access to food for all people must be improved substantially. Biodiversity loss and global food security are hence two major challenges of our time. Linking these two areas from a research perspective and seeking synergies between them are likely to generate multiple benefits for social, ecological, and economic development.

In October 2014, 108 scientists met in Aix-en-Provence, France, to explore these issues. Drawing on a French-German Network of collaboration, established by the Centre National de Recherche Scientifique (CNRS) and the LeibnizGemeinschaft (WGL), an international conference was organized at the Mediterranean Institute of Biodiversity and Ecology (IMBE), aiming to "identify science-based solutions for global sustainability focusing on the issues of biodiversity and food security." During sessions on "Environmental Changes and Food Security," "Green economy, food security and biodiversity," "Sustainable use of biodiversity," "Conceptual pitfalls in the food-biodiversity nexus," and "Science-based opportunities to reconcile food security, bio-
Wolfgang Cramer

wolfgang.cramer@imbe.fr

1 Institut Méditerranéen de Biodiversité et d'Ecologie marine et continentale (IMBE), Aix Marseille Université, CNRS, IRD, Avignon Université, Technopôle Arbois-Méditerranée, Bât. Villemin - BP 80, F-13545 Aix-en-Provence cedex 04, France

2 Fondation Rovaltain, Alixan, France

3 Faculty of Sustainability, Leuphana University Lüneburg, Scharnhorststrasse 1, 21335 Lüneburg, Germany

4 ISOE - Institute for Social-Ecological Research, Hamburger Allee 45, 60486 Frankfurt, Germany
5 Senckenberg Biodiversity and Climate Research Centre, Senckenberganlage 25, 60325 Frankfurt, Germany

6 CNRS, Laboratoire Montpelliérain d'Economie Théorique et Appliquée (LAMETA), Montpellier, France

7 UFZ - Helmholtz Centre for Environmental Research, Department of Community Ecology, Theodor-Lieser-Str. 4, 06120 Halle, Germany

8 German Centre for Integrative Biodiversity Research (iDiv), Halle-Jena-Leipzig, Deutscher Platz 5e, 04103 Leipzig, Germany

9 Institute of Biological Sciences, University of the Philippines Los Baños, College, 4031 Laguna, Philippines

10 UMR SADAPT, INRA, AgroParisTech, Université Paris-Saclay, 75005 Paris, France 
diversity conservation and sustainable development", overall 81 plenary and poster presentations were given. A selection of papers is provided in this special issue.

Several conceptual studies illustrate new approaches to address conflicts and synergies between the enhancement of food security and the conservation of biodiversity. Bernard and Lux (2017) use socio-ecological discourse analysis to discuss whether-and if so how much — more food needs to be actually produced to meet the future demand, how productivity could be increased sustainably, and how agroecology can be scaled up to these demands. Wittman et al. (2017) argue that rural landscapes should be re-conceptualized as social-ecological systems and illustrate their approach for the Brazilian Cerrado region. Through a structured literature review, Glamann et al. (2017) identify the contrast between biophysical-technical and social-political approaches to understanding food security and biodiversity conservation, showing that increased exchange between these communities is needed. Salles et al. (2017) argue that an economic perspective could contribute to the discussion on land sparing versus land sharing, for example by pointing out that the assumption of a fixed agricultural production target is not realistic. They also show that the consideration of productivity differences in such policies may strengthen the potential contribution of land sharing policies to the conservation of biodiversity.

A series of regional studies offers examples for progress that can be made. For olive-oleaster ecosystems in Morocco, Aumeeruddy-Thomas et al. (2017) demonstrate the similarity between ancient and modern practices in olive cultivation and how these contribute not only to food security but also to cultural identity. Bortolotto et al. (2017) show how, in the Brazilian Cerrado and Pantanal, knowledge networks can be designed to improve the economic condition of rural communities while also strengthening food security and valorizing biodiversity and local culture. For Mexican wetlands, González-Marín et al. (2017) study the use of wildlife for food security and the risks for this use from water pollution, hunting practices, and deforestation. In Philippine rice fields, Horgan et al. (2017) found that ecological engineering can have multiple benefits for farmers and the environment, including improved nutrition for farming communities, the creation of habitat for wildlife, and the enhancement of regulatory ecosystem services provided by insectivorous and snaileating birds.

In Burkina Faso, Koffi et al. (2017) show how, in woodlands and open landscapes, households shape their adaptive strategies differently depending on the resources available and the structure of the landscape, ensuring a significant contribution of forest resources to their food security. For semi-arid silvopastoral systems in Chile, Root-Bernstein et al. (2017) show that transhumant rewilding of guanacos has the potential to contribute to food security and sustainable agricultural production. In a simulation study for France, Teillard et al.
(2017) compared intensification, extensification, and reallocation of agricultural areas at fine scale, identifying potential "win-no loss" cases with near zero additional costs for agricultural production. The study also shows that current mechanisms for agricultural policy are insufficient to implement such optimizations in French landscapes. For Uganda, Rwanda, and Burundi, Van Soesbergen et al. (2017) show that different socio-economic projections of areas of high agricultural development all lead to similar spatial patterns of habitat and biodiversity loss. To expand protected areas is crucial to avoid biodiversity losses in all three countries.

For Europe, Mouysset (2017) argues that it is possible to reconcile agriculture and biodiversity with public policies, since it is possible to increase simultaneously the economic and ecological performances of agricultural landscapes compared to the current trends. However, it is not possible to optimize this reconciliation easily in an economic context, since the different criteria cannot be maximized simultaneously, and some trade-offs emerge between economic and ecological criteria.

Finally, three studies consider biodiversity and food security at the global scale. According to Delzeit et al. (2017), allowing the expansion of cropland generally results in improved food security not only in regions where crop production rises but also in net importing countries such as India and China. But the estimated cropland expansion risks to affect highly biodiverse regions, pointing to the need for spatially detailed and context-specific assessments to understand the possible outcomes of different food security strategies. Reducing meat consumption has been shown to have strong potential for the mitigation of both climate change and biodiversity loss. Stoll-Kleemann and Schmidt (2017) study various factors that might influence associated policies, finding that a "health argument" or arguing for flexitarianism could be particularly promising to encourage reduced meat consumption. They recommend that emotional messages or new social norms could overcome current barriers such as cognitive dissonance. Rumpold et al. (2017) present an overview of possibilities to enhance the use of insect biodiversity not only as a human food resource but also as livestock feed resource as well as for therapeutical and biotechnological applications.

In combination, these contributions paint a rich picture of the multi-facetted challenges associated with securing sufficient, healthy food for all of humanity while drawing on and conserving biodiversity. Solutions for reconciling biodiversity and food security require more than just controlling the environmental footprint of food production. The papers convey the picture that food security is under threat by interacting changes in biodiversity and its inherent biophysical structures and processes with changes in social, cultural, and socioeconomic structures and processes. This special issue highlights the analytical basis and reasonable starting points for the pathways towards achieving the sustainable development goals. 
Acknowledgements The conference benefitted from generous support provided by the CNRS and WGL and local support from the IMBE and Aix Marseille University. Additional financial support came from the Région Provence Alpes Côte d'Azur, ECCOREV, LabEx OT-Med, and the French Embassy in Germany. We thank the members of the organizing committee and the scientific committee, as well as IMBE staff members for all their support and good spirits. The conference was a contribution to the Future Earth ecoSERVICES project, as well as to BioDivMex-MISTRALS. This special issue would not have been possible without the help of the following scientific reviewers: David Abson, Jules Bayala, Neil Collier, Hans Dagevos, Anne de la Vega-Leinert, Martin Drechsler, Chris Elphick, Elin Enfors, Karlheinz Erb, Polly Ericksen, Charles A. Francis, Stephen T. Garnett, Augusto Hauber Gameiro, Klaus Henle, Valérie Heuzé, Daniel Kaniewski, Naoki Katayama, Marcel Kok, Christian Körner, G. Page Kyle, Louis Lebel, Heera Lee, Pia Lentini, Pablo Manzano, James Moore, Felicia OlmetaSchult, Unai Pascual, Martin Quaas, Cibele Queiroz, Peter Roebeling, Regine Schönenberg, Gorm Shackelford, Richard C. Smardon, Félix Teillard, Arnold van Huis, Peter Verburg, Keith Wiebe, and Eglee Zent.

\section{References}

Aumeeruddy-Thomas Y, Moukhli A, Haouane H, Khadari B 2017 Ongoing domestication and diversification in grafted olive-oleaster agroecosystems in Northern Morocco. Regional Environmental Change

Bernard B, Lux A (2017) How to feed the world sustainably: an overview of the discourse on agroecology and sustainable intensification. Reg Environ Chang. doi:10.1007/s10113-016-1027-y

Bortolotto IM, Hiane PA, Ishii IH, de Souza PR, Pires Campos R, Bastos Gomes RJ, da Silva FC, Leme FM, do Carmo de Oliveira Arruda R, de Lima Corrêa da Costa LB, Damasceno-Junior GA (2017) A knowledge network to promote the use and valorization of wild food plants in the Pantanal and Cerrado, Brazil. Reg Environ Chang. doi: 10.1007/s10113-016-1088-y

Delzeit R, Zabel F, Meyer C, Václavkí T (2017) Addressing future tradeoffs between biodiversity and cropland expansion to improve food security. Reg Environ Chang. doi:10.1007/s10113-016-0927-1

Glamann J, Hanspach J, Abson DJ, Collier N, Fischer J (2017) The intersection of food security and biodiversity conservation: a review. Reg Environ Chang. doi:10.1007/s10113-015-0873-3
González-Marín RM, Moreno-Casasola P, Castro-Luna AA, Castillo A (2017) Regaining the traditional use of wildlife in wetlands on the coastal plain of Veracruz, Mexico: ensuring food security in the face of global climate change. Reg Environ Chang. doi:10.1007/s10113016-0955-X

Horgan F, Ramal AF, Villegas JM, Almazan MLP, Bernal CC, Jamoralin A, Pasang JM, Orboc G, Agreda V, Arroyo C (2017) Ecological engineering with high diversity vegetation patches enhances bird activity and ecosystem services in Philippine rice fields. Reg Environ Chang. doi:10.1007/s10113-016-0984-5

Koffi CK, Djoudi H, Gautier D (2017) Landscape diversity and associated coping strategies during food shortage periods: evidence from the Sudano-Sahelian region of Burkina Faso. Reg Environ Chang. doi: 10.1007/s10113-016-0945-z

Mouysset L (2017) Reconciling agriculture and biodiversity in European public policies: a bio-economic perspective. Reg Environ Chang. doi:10.1007/s10113-016-1023-2

Root-Bernstein M, Guerrero-Gatica M, Piña L, Bonacic C, Svenning J-C, Jaksic FM (2017) Rewilding-inspired transhumance for the restoration of semiarid silvopastoral systems in Chile. Reg Environ Chang. doi:10.1007/s10113-016-0981-8

Rumpold BA, Klocke M, Schlüter O (2017) Insect biodiversity: underutilized bioresource for sustainable applications in life science. Reg Environ Chang. doi:10.1007/s10113-016-0967-6

Salles J-M, Teillard F, Tichit M, Zanella M 2017 Land sparing versus land sharing: an economist's perspective. Regional Environmental Change

Stoll-Kleemann S, Schmidt UJ (2017) Reducing meat consumption in developed and transition countries to counter climate change and biodiversity loss: a review of influence factors. Reg Environ Chang. doi:10.1007/s10113-016-1057-5

Teillard F, Doyen L, Dross C, Jiguet F, Tichit M (2017) Optimal allocations of agricultural intensity reveal win-no loss solutions for food production and biodiversity. Reg Environ Chang. doi:10.1007/ s10113-016-0947-x

Van Soesbergen A, Arnell AP, Sassen M, Stuch B, Schaldach R, Göpel J, Vervoort J, Mason-D'Croz D, Islam S, Palazzo A (2017) Exploring future agricultural development and biodiversity in Uganda, Rwanda and Burundi: a spatially explicit scenario-based assessment. Reg Environ Chang. doi:10.1007/s10113-016-0983-6

Wittman H, Chappell MJ, Abson DJ, Kerr RB, Blesh J, Hanspach J, Perfecto I, Fischer J (2017) A social-ecological perspective on harmonizing food security and biodiversity conservation. Reg Environ Chang. doi:10.1007/s10113-016-1045-9 